\title{
T. Nicklas
}

\section{ANCIENT CHRISTIAN CARE FOR PRISONERS: FIRST AND SECOND CENTURIES}

\begin{abstract}
This study deals with the question as to whether first- and second-century sources reflect ancient Christian practices of care for prisoners and in how far these sources help clarify the reasons why Christians cared for prisoners in different contexts. The study explores material not only from the New Testament Gospels (Matt. 25; Luke 4) and Acts, but also from the Pauline Corpus and extra-canonical literature such as Ignatius of Antioch's Epistles, later Acts of the Apostles, Martyrdom literature and even a passage from Lucian of Samosata's Life of Peregrinus. The article concludes that the evidence for Christian care for prisoners is earlier and more widespread than usually assumed. While some sources do not reflect on reasons for this practice, others put it into wider horizons: Matthew links care for prisoners with the notion that actions toward people in need are actions toward Christ, the judge himself - an innovative view that is certainly tied to the special circumstances of early Christians. Luke, however, borrows Isaianic motifs, linking freedom for captives with the Messianic Age.
\end{abstract}

\section{INTRODUCTION}

In his reference monograph on prisons in the Roman Empire, Jens-Uwe Krause (1996) devotes a section to the charitable activities of Christians towards prisoners in late antiquity. His main points can be summed up as follows (Krause 1996:316-323):

Prof. Tobias Nicklas, Katholisch-Theologische Fakultät, University of Regensburg, Germany \& Research Fellow, Department of New Testament, Faculty of Theology, University of the Free State, South Africa. E-mail: tobias.nicklas@theologie.uniregensburg.de 
1. In many instances, various authors from different times and geographical locations (Augustine, Zeno of Verona, Ambrose of Milan, Caesarius of Arles, John Chrysostom) mention care for prisoners in lists of typical Christian charity.

2. This care mainly consisted of concrete material support, which could mean supplying prisoners with food or other necessities as well as freeing them from prison by financial means. According to John Chrysostom, even poor Christians could support prisoners by visiting them or by trying to persuade the prosecutors or guards to treat the prisoners in a (more) humane manner. Krause gives examples where this social engagement led to the conversion of former prisoners, the most prominent being the later ascetic leader Pachomius.

3. While Tertullian and the Syrian Didascalia emphasised that Christian charity for prisoners should concentrate solely on Christians, this distinction did not play a major role for many later authors: prisoners were regarded as victims of a more or less unjust system, even if they had not been arrested because of their Christian beliefs, but as criminals. Such an estimate is understandable in light of a system abounding with corruption and the inhumane circumstances of imprisonment.

Although Krause indicates that care for prisoners is in line with earliest Christian practice, his sources start more or less with Tertullian and he focuses on the post-Constantinian era. In addition, as a socio-historian, Krause is mainly interested in social realities and less in theological reasoning. ${ }^{1}$ This leads to the following questions:

1. Even if, as far as I know, there are no Christian sources prior to the third century that systematically treat the issue of care for prisoners, it is worth asking whether and to what extent first- and second-century Christian sources (perhaps only indirectly) reflect practices like (or different from) the ones mentioned by Krause. ${ }^{2}$

2. A closer scrutiny of relevant sources may help clarify the reasons why Christians cared for prisoners in different contexts.

I shall treat the relevant sources not only along a partly hypothetical timeline, but also according to formal criteria.

1 In addition, one could object that he seems to understand Christianity in late antiquity as if it were a single "block" movement and treats all sources in the same manner, that is, he does not distinguish between homilies, treatises, hagiographic literature, and so on.

2 Regarding sources relevant for the (horrific) conditions in ancient prisons, cf. Wansink (1996). 


\section{AN APOCALYPTIC SPEECH AND ITS LATER USE: MATTHEW 25:36b-25:39, 43}

Although the Sermon on the Mount does not address the treatment of prisoners, the topic plays a role in Matthew's scene of the final judgement, which describes the Son of Man separating the sheep from the goats. The decisive criterion he applies is a person's behaviour towards others in need. The relevant list of examples is repeated several times and relates to those who are hungry, thirsty, strangers, naked, sick, and, finally, those in prison. ${ }^{3}$

Regarding the prisoners, I note the following variations:

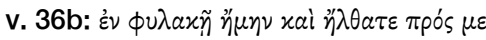
In agreement with

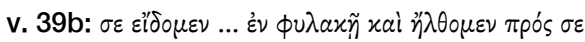

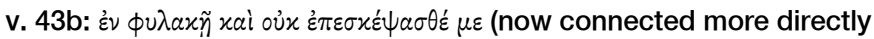 with the behaviour towards the "sick" one)

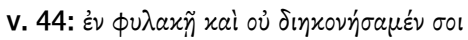

Even with their slight variations, these passages explicate the kind of thinking and behaviour that was expected from followers of Christ. A prisoner should not be viewed primarily as a criminal, but as a person in great need and thus comparable to someone suffering from hunger, thirst, sickness, cold, or as a helpless stranger. Whenever possible, one should visit prisoners (vv. 36, 39) and care for them (v. 43). The final variation (v. 44), however, could be understood differently: with its emphasis on "serving"

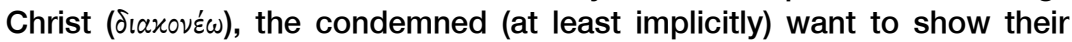
devout stance towards Christ (called "the Lord", in this instance). In his answer, Christ links people's deeds towards the needy with what they do to him. In other words, according to Matthew, justice (cf. v. 37) is directly related to good deeds towards persons in need, among them prisoners. ${ }^{4}$ This is clearly grounded theologically: to help a person in need means to help Christ himself; to treat this person appropriately means to treat Christ himself properly. And Christ is the Son of Man who will return for the final judgement - a judgement according to a person's relation to Christ, which is expressed in deeds. This text does not, of course, explicitly discuss

3 Michaels (1965) argued that the prisoners mentioned in Matthew 25 are not merely the needy, but early Christian missionaries. In my opinion, the text gives no clear hint of such an interpretation.

4 The issue concerning the Gospel of Matthew's relation to the Torah's notion of "justice according to deeds" is discussed in detail in Deines (2004), who, however, does not discuss Matthew 25 explicitly. 
or systematically reflect a general Christian practice (and, unfortunately, it is neither reflected in texts closely related to Matthew's community, such as the Didache or the Epistle of James). Nevertheless, apart from a related practice within at least parts of the Matthean community, such a text would be incomprehensible. It is interesting to note that the text does not show any sign of limiting this practice to fellow Christians (or members of the broader Jewish community, to which Matthew's group perhaps still belongs). ${ }^{5}$ The text may share ideas with Isaiah $56: 6-10$ of a universality of justice (cf. also Fiedler 2006:377).

Both the idea that the final judgement will be "according to deeds" and the existence of lists of deeds important for the final judgement are nothing new and are well attested in early Jewish literature (Isa. 58:7; Ez. 18:7, 16; Job 22:6-7; 31:17, 19, 21, 31-32; Tob. 1:16-17; 4:16; Sir. 7:34-35; 2 Enoch $9: 1 ; 42: 8 ; 63: 1)$. The element of "being in prison", however, is rarely found in non-Christian writings. Ulrich Luz (1997:535), therefore, considers this a special Christian emphasis that arose due to the fact that early Christian missionaries were always in danger of being imprisoned. This may be correct; I do not have a better explanation. A slight hesitation, however, is justified. After all, the Matthean Christ never speaks about "Christian" prisoners or care for captive brothers and sisters belonging to the community. At least, in this matter, the boundaries of the community seem irrelevant for Matthew.

\section{A SPECIAL HOMILY - AND LUKE 4:18 IN THE CONTEXT OF LUKE-ACTS}

Matthew 25 and its eschatological setting is certainly not the only New Testament passage in which the topic of prisons or prisoners occurs; nor is it the only one that allows us to draw conclusions about early Christian practices and their theological motivation. Perhaps more than any other Gospel, Luke emphasises the social dimension of Jesus' message. ${ }^{6}$ This becomes clear from the first scene of Jesus' public mission, namely in the synagogue of Nazareth (Luke 4:16-30) where he not only openly reads a combination of different passages from the book of Isaiah (Isa. 61:1-2 LXX; 29:18 and 58:6 LXX), but also gives a very short homily on these texts: "Today this Scripture has been fulfilled in your ears" (Luke 4:21). In

5 The question about whether Matthew's community can still be regarded as part of the "synagogue" has received a great deal of attention. For an overview, cf., for example, Senior (2011:6-15).

6 Cf. Luke 1:46-55, where this is connected to God's manner of acting. Cf., for example, Gradl (2005). 
other words, he is not only the Anointed One proclaimed in Isaiah 61:1; his "gospel" is also "good news to the poor, he is sent to proclaim release to the captives, recovery of sight to the blind and to let the oppressed go free" (adapted from NRSV). According to Luke, Jesus' Messianic programme is thus taken from Isaianic ideas about the end of times. Freedom for captives - who are, again, not viewed as criminals to be punished, but as human beings in need - figures prominently in this programme. Although the Gospel of Luke tells about Jesus' good news for the poor (Luke 6:20; 16:19-31) and the healing of a blind person (Luke 7:21; 18:35-43), one never reads about a prisoner freed by Jesus. The topic, however, resurfaces in Luke's second volume, the Book of Acts, where one reads, on several occasions, about the miraculous release of the apostles from prison. ${ }^{7}$ According to Acts 5:17-21, it is the entire group of the apostles that is freed by an "angel of the Lord", who opens the doors of the prison at night (Acts 5:19). Even more prominent is Acts 12:6-19a, Peter's miraculous release from prison and, finally, Acts 16:23-40 where one reads about Paul and Silas released from a prison in Philippi through a miraculous earthquake. Of course, these texts do not mention anything about early Christian practice towards prisoners. It is, however, noteworthy that, in all of the examples, the miraculous release is connected to the "Lord" perhaps the clearest example is Acts 12:11, where Peter recognises that "it is the Lord" who has sent his angel to set him free from prison.

The Book of Acts does not portray all Christian prisoners as being set free. The first indication of this is the martyrdom of James, the brother of Zebedee (Acts 12:2). More generally, from Acts 21:33 onwards, the text mentions Paul's imprisonments in Jerusalem, in Caesarea, and later in Rome. While in prison, the Lord tells him (in a vision?) that he will have to bear witness in Rome (Acts 23:11; cf. also 27:23, where an angel appears to him). Despite what was prophesied in Luke 4:18, Acts does not offer a vision in which every prisoner is released - such a description would not, of course, have been very realistic in a text claiming to be historiographic. ${ }^{8}$ Unfortunately, even the final chapters of Acts - abounding in passages about Paul as a prisoner - do not give ample evidence about the manner in which the Christian community may have supported Paul. One hears about Paul's nephew who remains in contact with his uncle and warns him (and the responsible chiliarch) of an attempt to lynch him (Acts 23:16-22). ${ }^{9}$ In addition, during his long stay in Caesarea - two years, according to

7 As Luke and Acts use different terminology for "prisoner", "imprisoned", and so on, the link is more topical than lexical.

8 For more information, cf. Frey et al. (2009).

9 Johnson (1992:404) regards this as evidence for an earlier stay of Paul in Jerusalem. 
Acts 24:27 - there must have been someone who supported him. Such support, however, cannot have been very strong. If one follows the comment in Acts 24:26 about Felix's desire to receive money from Paul (some

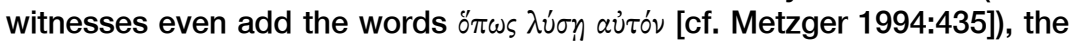
text at least implicitly considers it plausible for Paul to be freed by means of a bribe. This, however, does not happen. ${ }^{10}$ Only Chapters 27-28 give some explanatory information regarding Paul's support in prison. Beginning in Acts 27:1, the story is told in the first person plural, thus creating the impression that there must have been Christian companions of Paul who accompanied him on his journey to Rome. Acts 27:3 is even more explicit. According to this passage, Paul is allowed to go to his "friends" who take care of him. As this stop occurs in Sidon, it seems probable that these friends are not inhabitants of the city, but people travelling with him on the same ship. Acts 28:14-15 speaks about a meeting with "brothers" upon the group's arrival in Puteoli - and the entire group is allowed to stay with them for seven days. According to verse 15, others had informed these brothers about Paul's (and his companions') arrival. Acts 28:30, finally, depicts Paul's prison as a place of mission. Of course, one cannot be absolutely certain about the exact degree of historicity of the final chapters of Acts. While Chapter 27 is interested in the miracles occurring on the journey, the lack of concrete details about the situation in Rome in Chapter 28 can give the impression of theological construction rather than historical recollection (Omerzu 2001:127-156). Although passages such as Acts 27:3 are narrated without any special emphasis and thus seem to be based on historical information, the story of the meeting with the "brothers" in Puteoli could also be constructed because of Luke's emphasis on the overall unity of the "Way". It is interesting to note that one no longer reads anything about Christian communities in Rome in Chapter 28.

Thus, according to Luke 4:18, the release of captives is a sign of the dawn of the Messianic Era, which started with Jesus' mission and continues in the time of the Spirit. This does not mean that every prisoner is released from captivity. The Gospel itself does not show a clear interest in the fate of prisoners, but in Acts there are several "Christian" prisoners such as the group of apostles, as well as Peter and Paul. Whether the Lord or one of his angels miraculously releases them, or whether they have to stay in prison depends on whether their stay in prison is important for furthering the "way of salvation" (cf. Klein 2005:105-18). The narrative of Luke-Acts does not directly tell us anything concrete about care for prisoners. It does, however, show that, from its early inception, the Christian movement was

10 It is interesting to note that there is no sign of solidarity from the Jerusalem community, to which Paul intended to hand over his collection of money. 
confronted by persecution, on the one hand, and the Lord's will to free the captives, on the other.

\section{4. (DIRECT AND INDIRECT) EPISTOLARY EVIDENCE}

The most well-known prisoner in early Christianity is Paul - one reads in Acts about his (rather short) imprisonment in Philippi and his incarcerations in Jerusalem, in Caesarea, and, finally, in Rome. Another imprisonment in Ephesus is often assumed. Although Paul's letters never discuss how early followers of Christ should treat prisoners, they offer some indirect evidence that, as a prisoner, Paul was not left alone in his difficult situation. I shall mention a few examples.

\section{Example 1}

Several authentic Pauline Letters, including Philemon and Philippians, indicate that Paul was writing as a prisoner. ${ }^{11}$ Although scholars dispute whether Paul wrote Philippians from Rome or from Ephesus (cf., for example, Löhr 2013:206), the text abounds in details that relate to imprisonment. As a prisoner (Phil. 1:7, 12-13; cf. also 1:30), Paul seems to be in chains (Phil. $1: 17)$ and cannot be certain as to whether he will survive his desperate situation (Phil. 1:20-26; 2:17); yet he is able to prepare a letter to the Philippian community. This is an indication that he is not isolated from the rest of the world: his main contacts seem to be Timothy and Epaphroditus. Timothy is not only mentioned as Paul's co-author (Phil. 1:1) - perhaps Paul dictated the letter to him - but Paul also plans to send him imminently to Philippi and expects to hear news from the Philippians upon his return (Phil. 2:19). Epaphroditus, who seems to have been sent by the Philippians to support Paul in his imprisonment (Phil. 2:25), is Paul's main link to the Philippian community. Through him, Paul seems to know a fair amount about the situation in Philippi and even about concrete persons such as Euodia and Syntyche, whom he admonishes in 4:2. Paul also seems to have received a gift supporting him in his difficulty (Phil. 4:14, 18). Paul is not only aware of Epaphroditus' severe illness and recovery, but he is also in a position to send him back to Philippi. Timothy and Epaphroditus, however, are obviously not Paul's only contacts: he speaks about the growing

11 Other (authentic) Pauline letters allude only indirectly to the details of Paul's imprisonment: The clearest passage is 2 Corinthians 11:23 (in the context of the autobiographical passage in 11:21-33). Romans 16:7 mentions Andronicus and

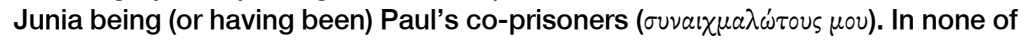
these passages, however, can one deduce any concrete details about life as a prisoner or about people who remained in contact with, and served prisoners. 
confidence of "most brothers" (Phil. 1:14) as a result of his imprisonment. This might, of course, overstate the actual situation. Nevertheless, such a statement is not possible apart from contact with the rest of the community. Finally, Paul sends greetings from "all the holy ones, especially those from the Emperor's house" (Phil. 4:22). Since it is unlikely that Paul would send greetings from people with whom he had not been in recent contact (to create the impression of a "Christian" community that did not really exist?), it is likely that Paul associated with, and was served by more people than simply Timothy and Epaphroditus. Only such a broad network of contacts would enable him to send both of his co-workers to Philippi.

The situation in Philemon is somewhat comparable. The Epistle also mentions Timothy as Paul's co-author. Even as a prisoner (vv. 1, 9-10), Paul is able not only to write a letter to Philemon and the members of his house church, but also to establish a special relation with Onesimus, Philemon's slave. Although it is doubtful that Onesimus was a runaway-slave (cf. Lampe 1985) - in such an instance, meeting Paul in prison would have simply been too dangerous - his concrete legal status is not completely clear. ${ }^{12}$ The text indicates that Paul may have baptised Onesimus in prison (v. 10) and sent him back to his master Philemon (v. 12), even though Paul would have preferred to have Onesimus stay with him and serve him in prison. In other words, Philemon's diaxovia is something Paul the prisoner could expect (v. 13; cf. also v. 20). Once again, Paul's final greetings are illuminating - he distinguishes between Epaphras, who is in prison with him, and his co-workers Mark, Aristarchus, Demas and Luke, who seem to be in contact with Paul, but are obviously not imprisoned (v. 23).

\section{Example 2}

Paul's imprisonment is also a recurring motif in (pseudepigraphical) Deutero-Pauline writings, among which I count Colossians, Ephesians, 2 Thessalonians and the Pastoral Epistles. Even if one cannot be certain about the extent to which the relevant passages reflect concrete historical situations in Paul's life, they should not be dismissed too readily, since even a pseudepigraphical letter must be realistic if it is to be regarded as authentic.

Perhaps Colossians has the best likelihood of being authentic. Colossians 4:7-18 offers a series of information that closely mirrors the authentic letters: Paul is in prison - this time together with Aristarchus (Col. 4:10) - but he is in close and obviously regular contact with a team of helpers, including Tychicus, who is mentioned first (v. 7) and called a $\pi \iota \tau \tau \dot{s} s$ diáxovos, which at the very least can mean that he serves Paul in his need. Paul

12 For an up-to-date discussion, cf. Wolter (2013:212). 
is also able to send both Tychicus and Onesimus to Colossae and to send another message regarding Mark. In addition, Colossians 4:11 mentions a certain Jesus the Just, who, together with Mark, became consolation for Paul. Paul seems to be informed about Epaphras' work, sends greetings from Luke and Demas, and, according to $4: 18$, is able to write the final greeting with his own hand. This motif, which may serve to authenticate an inauthentic letter, creates the image of a Paul who, despite imprisonment, is able to dictate and sign a letter. Due to a network of co-workers serving him, this prisoner is still firmly in control.

The situation in Ephesians is comparable. Again, Paul is described as a prisoner (Eph. 4:1; 6:20) who is able to compose a long letter - this time the prescript does not mention a co-author - and to send out his helper Tychicus (6:21-22).

With even greater likelihood than Colossians and Ephesians, 2 Timothy is pseudepigraphic (cf., for example, Herzer 2013). The epistle portrays a Paul who, shortly before the end of his life, sent away many of his co-workers and is abandoned by others (cf. 2 Tim. 4:10-12). Luke at the very least is with Paul, whose situation still allows him to send a letter to Timothy, who also should bring Mark with him (2 Tim. 4:11b). Finally, even in Paul's seemingly desperate (possibly fictitious) situation, a few new names appear on the list of greetings, including Eubulus, Pudens, Linus, Claudia and all the brothers (2 Tim. 4:21b). This, again, creates the image of a Paul who is in contact with several concrete persons from the (obviously) Roman community.

\section{Example 3}

Although 1 Peter 5:13 speaks about "Babylon" and mentions sufferings (1 Pet. 4:19), in my view the Catholic Epistles do not provide evidence for this study. I shall, therefore, attend to the letters of Ignatius of Antioch. The authenticity of Ignatius' letters has been a focus of discussion for over a decade; at present, there is no consensus. ${ }^{13}$ Even if some of the texts of the so-called "middle recension" perhaps cannot be traced back to Ignatius himself (or if his writings were transmitted in an edited version), they still offer insights into how early Christians imagined (or could imagine) Ignatius' situation. According to Eusebius of Caesarea's Ecclesiastical History (h.e. 3:36:1), Ignatius was brought as a captive to Rome at a time near the end of emperor Trajan's reign (Trajan died in $117 \mathrm{CE}$ ). The letters of Ignatius demonstrate that imprisonment did not mean loss of contact with the outside world. Ignatius was able to write seven epistles, which, to some extent, can be read as his literary testament and which demonstrate that

13 For an overview, cf. Holmes (2006:90-92). 
he is informed about the communities' most urgent problems. The letters portray him as one who still wields the authority to give instructions about the organisation of church life. Several passages have direct bearing on my investigation. Despite being guarded by ten leopard-like soldiers (Rom. 5:1), delegations from several churches arrive to meet Ignatius during his stay in Smyrna. They find sufficient time to discuss their situation and urgent problems with him (cf. Eph. 1:2-3; Magn. 2; 6:1; Trall. 1:1). During his stay in the Troas, Ignatius also seems to have received information about the situation in Antioch (Phil. 10:1; Smyrn. 11:3; Polyc. 7:1). During the meeting in Ephesus, the Ephesian deacon Burrus (Eph. 2:1) is sent to Ignatius as a travel companion, helper, and secretary. Burrus is mentioned in several letters (Phil. 11:2; Smyrn. 12:1), as are other companions of Ignatius. Crocus is mentioned in Epistle to the Ephesians 2:2, who has "refreshed Ignatius in every way". ${ }^{14}$ It may be asked whether this refreshment is only spiritual in nature or whether it implies the active, concrete provision of food and other necessities. After the break in Troas, the text also mentions a certain Philon, a Cilician deacon who assists Ignatius (Phil. 11:1; Smyrn. 10:1) and, along with a certain Theus/Rheus Agathopus, clearly accompanies Ignatius from Antioch. The community in Smyrna treated both travelling companions with great hospitality (Smyrn. 10:1). The latter seem to have caught up with Ignatius in Troas (Smyrn. 13:1, or at least Philon has). Obviously, none of the men are prisoners: Philon and Theus/Rheus Agathopus come voluntarily, while Crocus and Burrus seem to have joined in Smyrna. The text possibly indicates (at least in Eph. 2:1) that Burrus could leave Ignatius before the completion of the journey. Thus, the specific individuals who visited and accompanied Ignatius when his ship was stationed in Ephesus and Troas illustrate the kind of support he received. As mentioned earlier, however, according to the Epistle to the Romans 10:1, Crocus was with Ignatius along with "many others". Of course, the term "many" leaves the circumstance vague. According to the Epistle to the Trallians 12:1, Ignatius sends his greetings "together with the churches of God that are present with me, people who have refreshed me in every respect, physically as well as spiritually", ${ }^{15}$ and, in the Epistle to the Romans 9:3, he speaks about the "love of the churches that welcomed me in the name of Jesus Christ rather than a mere transient". The latter quote references a very unique kind of hospitality, since it is expressed towards a prisoner making his way to Rome where he will die as a martyr. Lastly, the Epistle to the

14 Translations according to Holmes (2006); cf. also Romans 10:1, where his name is mentioned alongside "many others".

15 Among the "spiritual" dimensions of care for Ignatius, one hears regularly about intercessory prayers for him (cf. Phil. 5:1; Trall. 12:3; Rom. 3:2). 
Philippians 11:2 identifies the need for the community in Troas to carry the letter to the addressees.

The Epistle to the Romans mentions one additional aspect of ancient Christian care for prisoners. Ignatius expects to meet the Roman community (Rom. 1:1), but he is afraid that their love may misguide their actions towards him and prevent him from achieving his goal and desire (Rom. 1:2; 4:1), namely to be a true disciple of Jesus Christ and "a sacrifice for God" (Rom. 4:2). In other words, he seems to fear that the community will take action to free him or at least to change his fate - perhaps by financial means or by getting involved in the process. Ignatius' fear, however, only makes sense if he is aware of other instances, or perhaps a general practice, in which the Roman community offered not only material support to (Christian) prisoners, but also judicial mediation.

\section{OTHER NARRATIVE EVIDENCE}

I shall now explore some extra-canonical writings that provide narrative evidence about Christian imprisonments.

\section{Evidence 1}

Without question, the numerous scenes in the extra-canonical Acts of the Apostles that unfold in prisons or relate to them do not directly reflect (nor do they seek to reflect) historical realities. As ancient "romances", these writings seek to educate and entertain their readers. ${ }^{16}$ Their vivid accounts about the apostles (as heroes with almost superhuman powers rather than as everyday people who experience hunger, thirst, or even fear of what will come) and their mission during the first generation certainly do not mention a great deal about the true historical circumstances of those times. Nevertheless, the texts' "narrated world" cannot be totally unrelated to the worlds and experiences of the intended readers. For this reason, the many "prison scenes" in the apocryphal Acts do not contain much relevant material for this investigation. However, in the Acts of Andrew, the apostle uses the prison almost like a centre for his preaching, and for his pastoral and missionary activities. ${ }^{17}$ When Maximilla meets Andrew in prison (chapter 3, Vat.), she is not there to take care of him, but to meet him and hear more of his message. The situation is comparable to the Acts of Paul, including the Acts of Paul and Thecla. According to the Acts of Paul 3:18 (= Acts of Paul and Thecla 18), Thecla gives her bracelets to

16 Regarding discussions about their genre, cf. Klauck (2005:14-22).

17 Cf., for example, Chapter 14 in the Vaticanus version or the relevant passages in the Martyrdom of Andrew. 
the gatekeeper and a silver mirror to the jailor so that she can meet Paul in prison (cf. also 3:19f.). This is not a sign of care for Paul's need, but of her determination to meet Paul in person and to receive further instruction about the Christian message. Later, in the context of Paul's fight against wild animals in Ephesus, one hears of Artemilla, the wife of Diophantes, and Eubula sitting together with Paul - according to the context, this must be in prison - by day and night. Nothing, however, is said about the women providing food for the apostle or caring for him in his difficult situation. In the Acts of Thomas, the apostle's imprisonments never prevent him from receiving visitors. Thomas is miraculously freed $(A T h .119)$, but then returns to prison, where he is never regarded as a victim, but remains the story's Handlungssouverän. These scenes are certainly not based on memories of historical events. Rather, they seek to show that, despite the apostle's imprisonment and impending martyrdom, evil powers cannot hinder the gospel of Jesus Christ. Although such texts show - at least in the "narrated world" of the early Christian romance genre - that the community of his followers never abandon an imprisoned apostle, their relevance for the present inquiry is minimal.

\section{Evidence 2}

At least some of the Acts of the Christian Martyrs - I shall concentrate on some of the third-century accounts and some that might be dated earlier ${ }^{18}$ contain short passages about the situation of the imprisoned martyrs awaiting their execution. Although these texts are usually considered historically more reliable than the apocryphal Acts, ${ }^{19}$ they are still written from the perspective of Christian devotees. In a similar manner to the Apocryphal Acts, the martyrs are described as examples for other believers and are idealised, while their sufferings and their heroic attitude are exaggerated. Some of these texts only reflect the concern of Christian communities - due in part to a rapidly growing interest in "relics" - to bury their martyrs properly (cf., for example, Mart. Pol. 18:2; Mart. Lugd. 59). Other texts offer some glimpses into the alleged situation of Christian prisoners. The Martyrdom of Potaemiana and Basilides briefly mentions Basilides' visit to the imprisoned Potaemiana; Chapter 11 in the Martyrdom of Pionius offers some description of Pionius' situation in prison; the most impressive text - I would say one of the most impressive writings in early Christianity - is the Martyrdom of Perpetua and Felicitas. The text is partly a diary of the martyr Perpetua herself and tells, in

18 Regarding dates and places of origin, cf. the relevant discussions in Barnes (2010) and Moss (2012).

19 This, however, depends on whether they belong to the genre of case records, "passions" of martyrs, or even (later) hagiographical literature. 
deeply moving ways, about Perpetua's feelings, pains, fears, and hopes. ${ }^{20}$ Perpetua's father visited her several times and tried to convince her to give up her convictions (cf., most impressively, Chapter 5), but a short passage in Chapter 3 gives the clearest account. According to 3:5-6, Perpetua and others were thrown into the inner dungeon of the prison where they suffered greatly. The situation changes because of the intervention of two deacons:

Tunc Tertius et Pomponius, benedicti diaconi qui nobis ministrabant, constituerunt praemio uti paucis horis emissi in meliorem locum carceris refrigeraremus. - Then Tertius and Pomponius, those two blessed deacons who tried to take care of us, bribed the soldiers to allow us to go to a better part of the prison to refresh ourselves for a few hours. (3:7; transl. Musurillo 1972.)

The passage clearly indicates that the Christian community not only sent two persons to minister to the Christian prisoners, but apparently also spent a certain amount of money to convince the guards to offer them a better treatment. In addition, the action of Tertius and Pomponius is described at the very least as if it was not unexpected, and perhaps as if it was self-evident on the part of the Christian community.

\section{Evidence 3}

A final piece of evidence is easily overlooked, since it does not come from a Christian text, but rather from Lucian of Samosata's late second century Death of Peregrinos - a strange caricature of the charlatan Peregrinos' life and career. It is interesting to note that this text portrays how a secondcentury pagan intellectual viewed Christians. A scene in Chapter 12 is especially revealing. ${ }^{21}$ Peregrinos is arrested because of his adherence to Christianity. As a Christian, he - of course, because of other Christians' incredible naiveté - rapidly takes over the function of a "prostate", writes books and is honoured like a God. His imprisonment, however, is not a matter of social shame, but brings him into even higher esteem. The Christians try everything possible to free him, and when they recognise that this is not possible, they offer him round-the-clock care - and "not just casually but with diligence". Widows and orphans wait at the prison, a church dignitary bribes the custodians to stay overnight with him, food is brought and the Holy Scriptures are read to him, and, finally, he is even called a "new Socrates". Although this description is a caricature, it is perhaps the most revealing of all the pre-third-century sources, since it is

20 For an up-to-date discussion, cf. Bremmer \& Formisano (2012).

21 Edition: Pilhofer et al. (2005). Regarding the text's image of Christians, cf. also Pilhofer (2005). 
impossible to make fun of something apart from a widespread, accepted image thereof. Obviously, Lucian is not only well informed about Christians, but he expects his readers to laugh about the image he draws. His joke, however, would fall flat if the image he creates was totally unknown to his readers.

\section{CONCLUSION}

Even in sources older than the ones mentioned by Krause, there is widespread, but partly indirect evidence of Christian care for prisoners. ${ }^{22}$ It is interesting to note that the motif of care for prisoners appears in genres as different as narrative literature, letters, and prophetic writings and can even be connected with eschatological ideas. In contrast to later times, the texts do not indicate whether care for prisoners should only be directed to Christians or to anybody in need. At least in Matthew, however, the argument is related to prisoners as human beings (and not as Christians) in need. The same text, however, does not explicitly mention anything about concrete practices in the Matthean community. Although the Christian sources I considered do not allow the various practices of different Christian groups to be distinguished, ${ }^{23}$ "care for prisoners" is such a common Christian practice that it can be made fun of, as Lucian's text demonstrates.

The various texts give different motives for taking care of prisoners. Although, in many instances, one can simply speak of acts of solidarity for the apostle, bishop, or missionary with whom a community is bound and connected, some writings place the idea of "care for prisoners" in a wider context. Both Matthew and Luke root their arguments in Jewish tradition. Matthew links care for prisoners with the notion that actions toward people in need are actions toward Christ, the judge himself - an innovative view that is certainly tied to the special circumstances of early Christians. Luke, however, borrows from Isaianic motifs, linking freedom for captives with the Messianic Age.

For outsiders such as Lucian, Christian care for prisoners - like the Christian movement in general - seemed rather strange. His jests about Christians relate less to their solidarity and more to their supposed naiveté. Lower class people who have been fooled by a Palestinian charlatan such as Jesus will, naturally, be silly enough to be fooled by a figure such as

22 Of course, some of the sources I mentioned may be contemporary or later than the oldest ones Krause mentions.

23 The question, for example, as to why Gnostic Marcionite Christians shared this practice with the emerging "majority" church cannot be answered because of a lack of sources. 
Peregrinus. But, even for the mocker Lucian, this does not mean that they are not impressively pleasant to each other, and especially to those in prison.

\section{BIBLIOGRAPHY}

BARnes, T.

2010. Early Christian hagiography and Roman history. Tübingen: Mohr Siebeck. Tria Corda 5.

Bremmer, J.N. \& Formisano, M. (Eds.)

2012. Perpetua's passions: Multidisciplinary approaches to the Passio Perpetuae et Felicitatis. Oxford: Oxford University Press. http://dx.doi.org/10.1093/acprof: osobl/9780199561889.001.0001

DEINES, $R$.

2004. Die Gerechtigkeit der Tora im Reich des Messias: Mt 5,13-20 als Schlüsseltext der matthäischen Theologie. Tübingen: Mohr Siebeck. WUNT 177.

FIEDLER, P.

2006. Das Matthäusevangelium. Stuttgart: Kohlhammer. Theologischer Kommentar zum Neuen Testament.

FreY, J., RothschILD, C.K. \& SchröteR, J. (Eds.) 2009. Die Apostelgeschichte im Kontext antiker und frühchristlicher Historiographie. Berlin/New York: De Gruyter. BZNW 162.

GRADL, H.-G.

2005. Zwischen Arm und Reich. Das lukanische Doppelwerk in leserorientierter und textpragmatischer Perspektive. Würzburg: Echter. Forschung zur Bibel 107.

HERZER, J.

2013. Die Pastoralbriefe. In: F.W. Horn (ed.), Paulus Handbuch (Tübingen: Mohr Siebeck), pp. 538-541.

Holmes, M.W.

2006. The Apostolic Fathers in English. $3^{\text {rd }}$ ed. Grand Rapids: Baker.

JOHNSON, L.T.

1992. The Acts of the Apostles. Collegeville, MN: Liturgical Press. Sacra Pagina.

KLAUCK, H.-J.

2005. Apokryphe Apostelakten. Stuttgart: Katholisches Bibelwerk.

KLEIN, H.

2005. Der Weg des Heils. Das theologische Konzept des Lukas. In: H. Klein, Lukasstudien (Göttingen: Vandenhoeck \& Ruprecht, FRLANT 209), pp. 105-118. 
Nicklas Ancient Christian care for prisoners: First and second centuries

Krause, J.-U.

1996. Gefängnisse im Römischen Reich. Stuttgart: Franz Steiner. Heidelberger Althistorische Beiträge und Epigraphische Studien 23.

LAMPE, P.

1985. Keine "Sklavenflucht" des Onesimus. ZNW 76:133-137.

LöHR, H.

2013. Philipperbrief. In: F.W. Horn (ed.), Paulus Handbuch (Tübingen: Mohr), pp. 203-210.

LUZ, U.

1997. Das Evangelium nach Matthäus (Mt 18-25). Zürich: Benziger \& NeukirchenVluyn: Neukirchener. EKK I/3.

Metzger, B.M.

1994. A textual commentary on the Greek New Testament. Stuttgart: Deutsche Bibelgesellschaft.

Michaels, J.R.

1965. Apostolic hardships and righteous Gentiles. JBL 84:27-37.

Moss, C.R.

2012. Ancient Christian martyrdom. Diverse practices, theologies, and traditions. New Haven, CT: Yale University Press.

MusuriLlo, H. (Ed.)

1972. The Acts of the Christian martyrs. Oxford: Clarendon. Oxford Early Christian Texts.

OMERZU, $\mathrm{H}$.

2001. Das Schweigen des Lukas. Überlegungen zum offenen Ende der Apostelgeschichte. In: F.W. Horn (ed.), Das Ende des Paulus. Historische, theologische und literaturgeschichtliche Aspekte (Berlin/New York: De Gruyter, BZNW 106), pp. 127-156.

Pilhofer, P. 2005. Das Bild der christlichen Gemeinden in Lukians Peregrinos. In: P. Pilhofer, et al. (eds.), Lukian. Tod des Peregrinos (Darmstadt: WBG, Sapere 9), pp. 97-110.

Pilhofer, P., Baumbach. M., Gerlach J. \& D.U. Hansen. (Eds.) 2005. Lukian. Tod des Peregrinos. Darmstadt: WBG. Sapere 9.

SENIOR, D.

2011. Matthew at the crossroads of Early Christianity: An introductory assessment. In: D. Senior (ed.), The Gospel of Matthew at the crossroads of Early Christianity (Leuven et al.: Peeters, BETL 243), pp. 3-24.

WANSINK, C.S.

1996. Chained in Christ: The experience and rhetoric of Paul's imprisonments. Sheffield: Sheffield Academic Press. JSNTSupp 130. 
WOLTER, M.

2013. Philemonbrief. In: F.W. Horn (ed.), Paulus Handbuch (Tübingen: Mohr), pp. 210-213.

Keywords

Ancient prisons

Early Christianity

Care for prisoners

Early Christian charitable practices
Trefwoorde

Antieke gevangenisse

Vroeë Christendom

Versorging van Christene

Vroeg-Christelike

liefdadigheidspraktyke 